\title{
Assessment of Chemical Characteristics of Low Chilling Peach Cultivars under Agro-climatic Conditions of Bihar
}

\author{
Kumari Madhumala, Karanjeev Kumar*, Sanjay Sahay and Feza Ahmad \\ Department of Fruit and Fruit Technology, BAU Sabour Bhagalpur, India \\ *Corresponding author
}

\section{A B S T R A C T}

\begin{tabular}{|l|}
\hline Key w or d s \\
TSS, \\
Peach, Sugar, \\
Acidity \\
\hline Article Info \\
\hline $\begin{array}{l}\text { Accepted: } \\
\text { 08 January } 2020 \\
\text { Available Online: } \\
\text { 10 February } 2020\end{array}$ \\
\hline \hline
\end{tabular}

Peach (Prunus persica L.) is one of the most important temperate stone fruit belongs to the family Rosaceae and sub family Prunoidae. Five peach cultivars like Shan-e-Punjab, Florda prince, Pratap, Early Grand, Prabhat, were cultivated for evaluation purposes to come up with a suitable cultivar for commercial production under agro-climatic conditions of Bihar, India. The experiment was laid out in a randomized block design with 4 replications at Bihar Agricultural College Sabour, Bhagalpur in the year 2018-19. Maximum TSS was found in Prabhat $\left(16.3^{\circ}\right.$ Brix) whereas minimum TSS was observed in Florda Prince $\left(10.7^{\circ}\right.$ Brix). Maximum acidity was found in Early Grand $(0.60 \%)$ while minimum acidity was observed in Pratap $(0.18 \%)$ which gave rise to maximum TSS/Acidity ratio (82.93) while minimum in Early Grand (24.00). Maximum total sugar $(15.18 \%)$ and non reducing sugar $(7.72 \%)$ was found in Florda Prince whereas minimum total sugar (10.66\%) was found in Early Grand and minimum non reducing sugar (5.40\%) was found in Shan-e-Punjab. Maximum reducing sugar found in Florda Prince (5.34\%) however minimum reducing sugar was observed in Pratap (3.04\%). Maximum ascorbic acid $(18.05 \mathrm{mg} / 100 \mathrm{~g}$ pulp) was found in Florda Prince while Minimum in Shan-e-Punjab $(10.45 \mathrm{mg} / 100 \mathrm{~g}$ pulp). Finally it can be concluded that Florda prince is the best cultivar followed by shan-e-punjab under agro-climatic conditions of Bihar.

\section{Introduction}

The peach (Prunus persica) is a deciduous tree native to the region of Northwest China between the Tarim Basin and the north slopes of the Kunlun Mountains, where it was first domesticated and cultivated. It bears an edible juicy fruit called a peach or a nectarine. The specific name persica refers to its widespread cultivation in Persia (modern day Iran), from where it was transplanted to Europe. It belongs to the genus Prunus which includes the cherry, apricot, almond and plum, in the rose family. Skin of the peaches are either smooth or velvety (peaches) and hairless (nectarines) in varied genotypes due to mutation in a single gene (Jana, 2015). Based on the grip of the flesh being free or rigid on the seed, peaches are divided into clingstone and freestone, depending on whether the flesh sticks to the stone or not both can have either white or yellow flesh. Peaches with white flesh typically very sweet with little acidity, while yellow fleshed peaches typically have 
an acidic tang coupled with sweetness, though this also varies greatly. Fruit of peaches are rich source of vitamins, proteins, sugars (sucrose) and minerals. It has anti-aging properties and also helps in detoxification, as well as improving digestion and cellular health.

The area and production of peaches in India during 2017 were 18.00 thousand hectare and 13 MT respectively ( $3^{\text {rd }}$ estimates of $\mathrm{NHB}$, 2017-18). The economic life of the peach is $12-20 \mathrm{yrs}$ for the commercial production. Peach cultivation is mostly strenuous in temperate region of the world diagonally all the continents. The predominance cultivars of peach have need of 200-850 chilling hrs. below $7.2^{\circ} \mathrm{C}$ and usually flourish in the spring. It require warmest climate of all temperate fruits so it can prefers for subtropical climatic conditions. Low chilling cultivars are grown in a submountaineous region of Punjab, Haryana, Delhi and western UP. yet, several current attempt comprise lead towards an expansion of chilly cultivars of peaches require 100-300 hours of chilling which can fruitfully developed in subtropical area (Nijjar and Khajuria, 1979).

The peach is classified with the almond in the subgenus Amygdalus, distinguished from the other subgenera by the corrugated seed shell. Due to their close relatedness, the inside of a peach stone tastes remarkably similar to almond, and peach stones are often used to make a cheap version of marzipan, known as persipan. Peaches and nectarines are the same species, even though they are regarded commercially as different fruits. In contrast to peaches, whose fruits present the characteristic fuzz on the skin, nectarines are characterized by the absence of fruit-skin trichomes (fuzz-less fruit). The flowers are produced in early spring before the leaves; they are solitary or paired, $2.5-3 \mathrm{~cm}$ diameter, pink, with five petals. The fruit has yellow or whitish flesh, a delicate aroma, and a skin that is either velvety (peaches) or smooth (nectarines) in different cultivars. The flesh is very delicate and easily bruised in some cultivars, but is fairly firm in some commercial varieties, especially when green. Cultivated peaches are divided into clingstones and freestones, depending on whether the flesh sticks to the stone or not; both can have either white or yellow flesh.

\section{Materials and Methods}

The present studies were carried out Bihar Agriculture University, sabour Bhagalpur during 2018-2019 on 7 yr old peach tree. Five peach cultivar namely, Early Grand, Florda Prince, Shan-e- Punjab, Prabhat, Pratap were evaluated for flowering and fruiting and fruit quality parameters the tree were planted at $2 \times 2 \mathrm{~m}$. The flowering behaviour were noted for all the cultivars visually. TSS of the fruit was estimated by Hand Refractrometer, acidity, ascorbic acid were described by Rangana (2010). Data were subjected to ANOVA test for Statistical Analysis under RBD.

\section{Results and Discussion}

The highest TSS content was recorded in Prabhat and lowest TSS in Florda Prince whereas as maximum acidity was found in Early Grand and minimum in Pratap $(0.18 \%)$ which gave rise to the highest TSS/ Acid ratio in 'Pratap' and lowest with 'Early Grand. The considerable difference in TSS among the different peach cultivars may be due to genetic constituent of various cultivars which subsequently affect the production of photosynthates and their supplementary breakdown of metabolites in simpler form. Difference in acidity level of fruits might be due to the presence of changing capacity of amount of organic acids in them. 
Highest ascorbic acid (18.05mg/100g pulp) was observed in Florda Prince While lowest ascorbic acid content $(10.45 \mathrm{mg} / 100 \mathrm{~g}$ pulp) was observed for 'Shan-e-Punjab. In the present study, result revealed the considerable difference among cultivar for their ascorbic acid content. The synthesis of ascorbic acid content in fruit depend upon sufficient supply of hexose Sugar, which decline at ripening stage might be due to diminish in acidity which would be attributed to oxidation of ascorbic acid.

Table.4.1 Performance of low chilling peach cultivars with respect to TSS, acidity, TSS/Acidity, ascorbic Acid in agro-climatic conditions of Bihar

\begin{tabular}{|c|c|c|c|c|}
\hline Variety & TSS ( $\left.{ }^{\circ} \mathrm{brix}\right)$ & Acidity (\%) & TSS: Acidity & $\begin{array}{c}\text { Ascorbic acid } \\
(\mathrm{mg} / \mathbf{1 0 0 g})\end{array}$ \\
\hline Early Grand & 14.4 & 0.60 & 24.00 & 17.10 \\
\hline Florda Prince & 13.25 & 0.22 & 60.97 & 18.05 \\
\hline Shan-e-Punjab & 15.2 & 0.31 & 49.57 & 10.45 \\
\hline Prabhat & 16.3 & 0.35 & 47.24 & 13.30 \\
\hline Pratap & 14.9 & 0.18 & 82.93 & 13.30 \\
\hline $\operatorname{Sem}( \pm)$ & 0.32 & 0.006 & 2.03 & 0.27 \\
\hline CD (0.05) & 1.00 & 0.02 & 6.28 & 0.83 \\
\hline CV (\%) & 4.53 & 4.19 & 7.71 & 3.72 \\
\hline
\end{tabular}

Table.4.6 Performance of low chilling cultivars of peach with respect to total sugar, reducing sugar \& non-reducing sugar in Agro-climatic conditions of Bihar

\begin{tabular}{|c|c|c|c|}
\hline Variety & Total Sugar (\%) & $\begin{array}{c}\text { Reducing Sugar } \\
(\%)\end{array}$ & $\begin{array}{c}\text { Non-reducing sugar } \\
(\%)\end{array}$ \\
\hline Early Grand & 10.66 & 4.00 & 6.86 \\
\hline Florda Prince & 15.18 & 5.34 & 7.72 \\
\hline Shan-e-Punjab & 10.04 & 4.57 & 5.40 \\
\hline Prabhat & 12.31 & 4.50 & 6.27 \\
\hline Pratap & 11.66 & 3.04 & 5.90 \\
\hline $\operatorname{Sem}( \pm)$ & 0.26 & 0.11 & 0.11 \\
\hline CD (0.05) & 0.81 & 0.33 & 0.34 \\
\hline CV (\%) & 4.38 & 4.93 & 3.47 \\
\hline
\end{tabular}


Maximum total sugars were recorded for 'Florda Prince (15.18\%) and lowest total sugars $(10.04 \%)$ were observed in 'Early Grand'. Maximum reducing sugars (5.34\%) were recorded for 'Florda Prince' and minimum reducing sugars $(3.04 \%)$ were recorded in 'Pratap'. The maximum nonreducing sugars $(7.72 \%)$ were recorded for 'Florda Prince' and minimum non-reducing sugar was observed in Shan-e-Punjab $(4.80 \%)$. The significant variations found in different low chilling peach cultivars may be due to different climatic variations influencing synthesis of bio-chemical constituent in the fruit developments and fruit development interval.

Dubey finding is in line of the work of Chaurasiya and Mishra (2017), Kishore et al., (2017) and Patel et al., (2007). Dubey (2003) also recorded different concentration of acidity in peach Varieties.

Finally it can be concluded that Florda prince is the best cultivar followed by shan-e-punjab in chemical characteristics under agroclimatic conditions of Bihar.

\section{References}

Chaurasiaya P.C and Mishra, R.K. (2017),
Varietal performance of peach (Prunus persica (L) Batsch) under northern hill zone of Chhattisgarh. International Journal of chemical Studies, 5(5), 3740.

Dubey A K. (2003). Studies on the performance of peach cultivars suitable for arid altitude of Arunachal Pradesh. Annals of Agricultural Research 24(3): 686-688

Jana BR. Performance of some low chill peach [Prunus persica (L.) Batsch] under eastern plateau regions of India. (2015); 4(12): 752-757.

Kishore A, Narayan R, Brijwal M, Attri LB, Kumar A, Debnath S. (2017). Comparative Assessment of Physiochemical characteristics among different Peach cultivars under Mid Hil conditions of Uttrakhand chemical science Review and letters, 6(23), 16771680.

Nijjar G S and Khajuria A N. (1979). New peach cultivars for Punjab. Punjab Hort. Journal, 19(12): 46-48.

Patel R K, Babu K D, Akath Singh and Yadav D S. (2007). Performance of low chilling cultivars under mid hills of Meghalaya. Environment and Ecology 25(1): 229-231.

\section{How to cite this article:}

Kumari Madhumala, Karanjeev Kumar, Sanjay Sahay and Feza Ahmad. 2020. Assessment of Chemical Characteristics of Low Chilling Peach Cultivars under Agro-climatic Conditions of Bihar. Int.J.Curr.Microbiol.App.Sci. 9(02): 1651-1654. doi: https://doi.org/10.20546/ijcmas.2020.902.190 